\title{
Gear Tooth Rooth Stress and Fillet Radii Dependence
}

Daniela S. Ristić

Assistant Professor Tehnikum Taurunum High School of Engineering Belgrade

Janez Kramberger

Assistant Professor University of Maribor Faculty of Mechanical Engineering Slovenia
Tooth root form and fillet radius have a great influence on gear tooth root strength that is one of the primary subjects of this paper. Special attention is given to analysis on impact of gear tooth fillet radius at the critical cross section on stress value and distribution. A first initial crack appears at the gear tooth and it is affected, the most, by root stress concentration. Hence, this paper's research topic is focused on finding the optimal fillet tooth root radius to minimize the tooth root stress intensity. This paper provides results achieved by application of numerical methods - finite element method (FEM) and real working conditions simulation. The results of this analysis are presented as figures and tables of Von Mises and normal stresses as well as charts against different values of tooth root fillet radius $\rho_{F}$ in two case: with one tooth root fillet radius $\rho_{F}$ and with two fillet radii $\rho_{F} 1$ and $\rho_{F 2}$ ("two level approach" in a root).

Keywords: finite element method-FEM, tooth root stress concentration, tooth root fillet radius.

\section{INTRODUCTION (ALL CAPS - HELVETICA 9 PT, BOLD) - ALIGN LEFT}

Form and dimensions of a tooth root fillet radius have great deal on stress concentration, initializing cracks and even fatigue failures appearance. Considering spur gears the greatest stress concentration appears in a tooth root $[10,11]$.

Tooth root critical cross section is determined by tooth fillet radius tangent that is positioned $30^{\circ}$ against gear symmetry line, and its dimensions are critical cross section width $s_{F n}$ and wheel width $b$ (Fig. 1) [1].

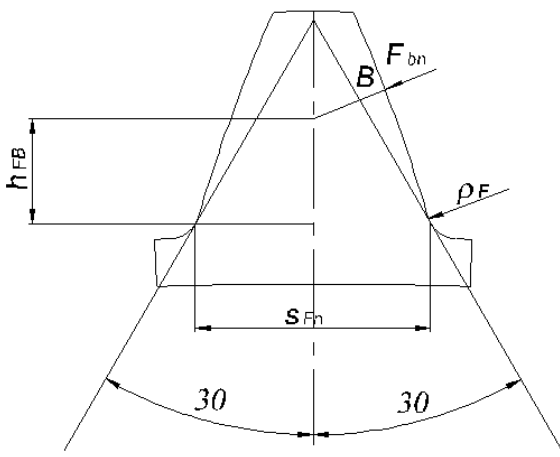

Figure 1. Driven gear with one fillet radius critical cross section dimensions and acting normal force $F_{b n}$ at the outer point of a single mesh $B$

According to the theory, at the contact points B and D (B - outer point of a single mesh, D - inner point of a single mesh), double mesh follow transforms to single and reverse. In that points Fbn force acts in total value (because of single mesh follow), while in points A and E, Fbn force acts with half of its total value. Hence, the greatest values of normal and equivalent stresses in the

Received: May 2014, Accepted: October 2014

Correspondence to: Daniela Ristic

Tehnikum Taurunum High School of Engineering,

Nade Dimic 4, 11080 Belgrade, Serbia

E-mail: daniela.ristic@gmail.com

doi:10.5937/fmet1404323R

(C) Faculty of Mechanical Engineering, Belgrade. All rights reserved tooth root appear in the moment when the contact between two meshed gears is in the outer point of single mesh and only results for this contact points will be presented. Loads in other mesh contact points have no big influence on critical cross section stress concentration and they don't cause failures and crack initiation in a tooth root.

Tooth root critical cross section is exposed to a pressure load under radial component, and under tangential component as bending and shearing. It all shows complex load state in the tooth root critical cross section. Accumulation of normal stresses gives maximal stress on pressured side of the gear tooth, while, in the same time, resulting normal stress on the tensile side is considerably less than on the pressured side of the gear. However, unwanted phenomenon as plastic deformations, crack initiation, even a gear failure appears on a stretched side of gear tooth which gives cracks initialization. According to that, rectangular tooth root cross section is deformed and goes to trapeze form, which leads to changes of the position of neutral axe. Because of that all, stress values on the stretched side of gear tooth are important for determination of applied stresses.

Tooth root stresses are very important for cracks initializations and failure appearance.

Authors of this paper investigated tooth root fillet radius influence on critical section stresses in two cases: with only one and with two fillet radii.

In this paper special attention will be dedicated to stress concentration comparison in gear tooth root with one and with two fillet radii ("two level approach" in a root) $[1,3]$.

Parameters that define tooth root geometry are presented on a Fig.1 and Fig.2.

Fig.2. presents tooth root with two fillet radius parameters where $\rho_{F 1}$ is upper radius and $\rho_{F 2}$ is lower radius. A critical section position is determined in the same way as for the tooth root with only one fillet radius. It is always possible to determine a critical 
section position for upper radius $\rho_{F 1}$, but for the lower radius $\rho_{F 2}$, critical section is near the top of the fillet radius and it is often impossible to be determined under the $30^{\circ}$ angle.

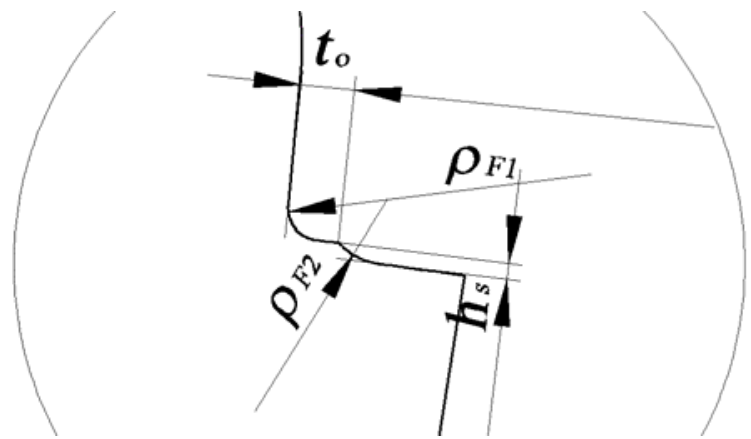

Figure 2. Gear tooth root parameters with two fillet radii

In case of one tooth root fillet radius it is analyzed eight different values of $\rho_{F}$. The lowest value is $\rho_{F}=$ $4.56 \mathrm{~mm}$ and it is incrementally increased to the value of $\rho_{F}=10.94 \mathrm{~mm}$. Fig. 1 shows parameters of critical section for tooth of a driven gear with only one fillet radius.

Tooth root fillet radius $\rho_{F}$ is given in the form of:

$$
\rho_{F}=\frac{c_{p}}{\left(1-\sin \alpha_{0}\right)}
$$

where $\alpha_{0}$ is main pressure angle $\left(\alpha_{0}=20^{\circ}\right)$ and $c_{p}$ can be determinated by $c_{p}=(0.1 \div 0.3) m,(m-$ module $)$.

\section{CHARACTERISTICS OF ANALYZED GEAR}

All analytical and numerical researches are carried out on a real construction with real condition simulation. Considered gear is a part of structural elements of great power planetary transmitter (big excavator of power $2 \times 550 \mathrm{~kW}$ ) with following characteristics [3,7-9]:

o module $m=24 \mathrm{~mm}$,

0 modification coefficients $x_{1}=0$ and $x_{2}=0.326$,

o wheel width $b=350 \mathrm{~mm}$,

o torque $T=2528.8 \mathrm{kNm}$,

o number of teeth $z_{1}=20$ and $z_{2}=96$,

o gear material is carbonized steel $17 \mathrm{CrNiMo6}$ (according to DIN) with Young's modulus $E=$ $2.1 \times 10^{5} \mathrm{MPa}$ and Poisons's ratio $v=0.3$.

\section{DETERMINATION OF THE GEAR LOAD CAPACITY ACCORDING TO TOOTH ROOT STRENGTH}

Tooth root applied load caused by normal force $F_{b n}$ acts in contact points on the mashed teeth profiles. For analyzing the stress conditions at the gear tooth root, the toot is approximated with the console shaped mechanical model, embedded in the gear body, at the end of which the load acts in the direction of the teeth profile pressure line.

Normal force can be divided in two components:

$0 \quad$ radial $F_{r}=F_{b n} \sin \alpha_{F a n}$ and

o tangential $F_{t}=F_{b n} \cos \alpha_{F a n}$, where the gear is exposed to a pressure load under radial component, and under tangential component, with the force $\operatorname{arm} h_{F a}$, it is exposed to bending and shearing. Normal force $F_{b n}$ is determined according to:

$$
F_{b n}=\frac{F_{t}}{\cos \alpha_{n} \cos \beta} \text {. }
$$

According to the theory, at the contact point B for the driven gear, double mesh follow transforms to single and reverse. In that point $F_{b n}$ force acts with total value. Loads in other mesh contact points have no big influence on critical cross section stress concentration and they don't cause failures and crack initiation in a tooth root. In this work shall be represented only results for the driven gear and its B contact point (Fig. 1).

It is possible to get analytical normal tooth root stress value according to (Fig.1) and [8] as follows:

$$
\sigma_{F n}=\frac{F_{t}}{b m_{n}} \frac{6\left(h_{F a} / m_{n}\right) \cos \alpha_{F a}}{\left(s_{F n} / m_{n}\right)^{2} \cos \alpha}
$$

Table 1 shows dimensions of a tooth root critical section with one fillet radius (Fig. 1) necessary for normal stresses determination for different values of tooth root fillet radius $\rho_{F}$.

Table 1. Dimensions of a tooth root critical section of the driven gear tooth with one fillet radius

\begin{tabular}{|c|c|c|}
\hline $\begin{array}{c}\text { Fillet radius } \\
\rho_{F}[\mathrm{~mm}]\end{array}$ & $s_{F n}[\mathrm{~mm}]$ & $h_{F}[\mathrm{~mm}]$ \\
\hline 4.56 & 55.637 & 26.166 \\
\hline 5.47 & 55.375 & 25.672 \\
\hline 6.38 & 55.141 & 25.263 \\
\hline 7.29 & 55.000 & 24.901 \\
\hline 8.22 & 54.859 & 24.540 \\
\hline 9.12 & 54.542 & 23.988 \\
\hline 10.03 & 54.422 & 23.544 \\
\hline 10.94 & 54.314 & 22.955 \\
\hline
\end{tabular}

Analysis is carried through without deviation in production process and at ideal contact conditions.

\section{NUMERICAL ANALYSIS}

Numerical analysis is deduced to determination of Von Mises stresses and normal stresses for a gear of planetary transmitter. That same gear is designed at the first analysis with one fillet radius $\rho_{F n}$ and at the second analysis with two tooth root fillet radius $\rho_{F 1}$ and $\rho_{F 2}$ with same or with different values. Finite element method (FEM) for numerical analysis is used [2,5,6]. For that purpose finite element package FEMAP v.9.3 is used.

On the basis of the gear data, the 3D finite element model is made. At first analysis (one tooth root fillet radius) one driven gear tooth has 11240 elements and 12915 nodes (Fig.3). At second analysis (two tooth root fillet radius) one gear tooth is formed by 11440 elements and 13000 nodes and it is formed in order to have the same number of nodes and elements as the same analyzed gears with only one tooth root fillet radius. The mesh is refined in the tooth fillet region in order to show the stress condition in that section as best as it is possible. According to a supposition that load is 
equally arranged along the instantaneous tooth side, only $50 \mathrm{~mm}$ width layer of tooth contact line is analyzed. The gear tooth is loaded with the normal force $F_{b n}$ which is acting with the whole value at the outer point of a single mesh (B).
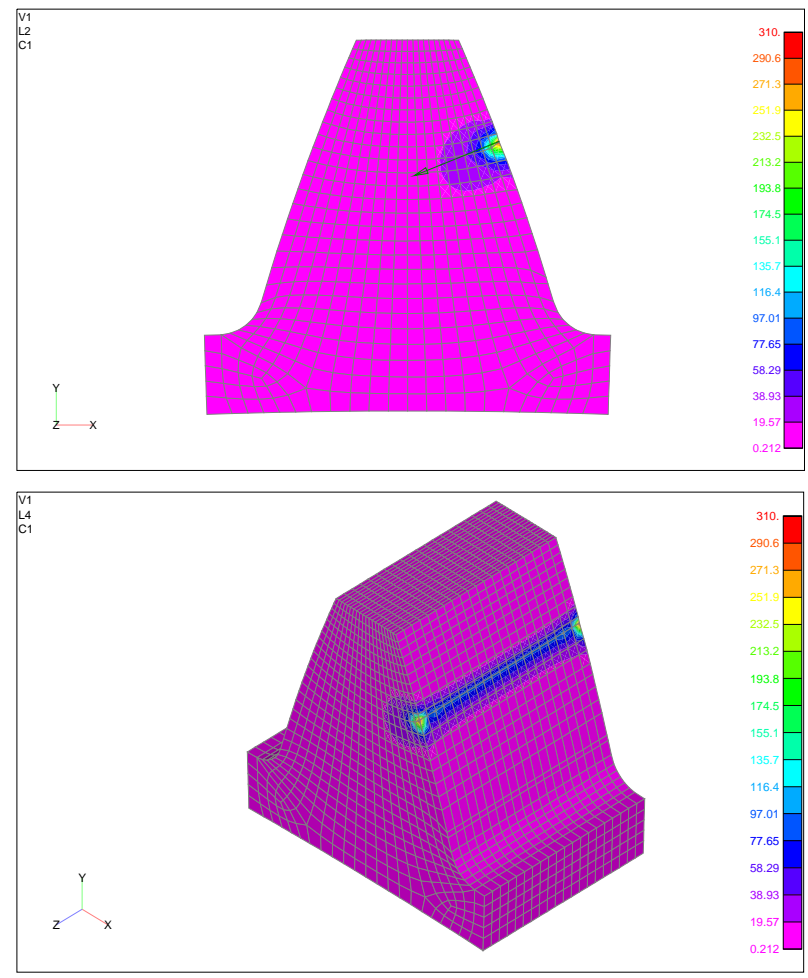

Figure 3. 3D finite element model for a gear tooth with one fillet radius and normal force $F_{b n}$ acting in the outer point of a single mesh $B$

Outer load, normal force $F_{b n}$, that it is equally arranged along the instantaneous tooth side contact line, is changed with concentrated force at nodes along that line ( 21 nodes along the width $b_{1}$ ). It is possible to get equal force distribution along the tooth width, if it is possible, to have more layers of finite elements and that sooths influence of concentrate force in the instant contact point.

Developed FEM (finite element method) of stress determination in gear tooth root allows not only good picture of stress distribution but even defines exact position of maximum stresses.

In this analysis are presented only numerical results for Von Mises and normal stresses at critical section on a stretched side.

Results of Von Mises $\sigma_{e}$ and normal $\sigma_{y}$ stresses at critical section of the gear tooth with one fillet radius caused by acting of a normal force $F_{b n}$ at the inner contact point B are presented in Table 2.

Results for the second analysis and for the both fillet radius $\rho_{F 1}$ and $\rho_{F 2}$ are shown in Table 3 . Stress values in these tables present tooth root stresses in a critical section. Stresses on a stretched side of a gear tooth critical section cause crack initializations and failures appearance, and that is the reason they are only presented in these Tables.

It may be seen from these tables that Von Mises $\sigma_{e}$ and normal $\sigma_{y}$ stresses become less as fillet radius $\rho_{F}$ grows up and it is in agreement with analytical results
$[7,8]$. So, there is a recommendation for higher values of fillet radius, but only in allowed boundaries.

Table 2. Von Mises $\sigma_{e}$ and normal $\sigma_{y}$ stresses at critical section of the gear tooth with one fillet radius

\begin{tabular}{|c|c|c|}
\hline $\begin{array}{c}\text { Fillet radius } \\
\rho_{F}[\mathrm{~mm}]\end{array}$ & $\sigma_{e}[\mathrm{MPa}]$ & $\sigma_{y}[\mathrm{MPa}]$ \\
\hline 4.56 & 161.3647 & 149.1460 \\
\hline 5.47 & 159.7299 & 144.1272 \\
\hline 6.38 & 157.9008 & 140.1133 \\
\hline 7.29 & 153.2990 & 135.1501 \\
\hline 8.22 & 151.0676 & 130.4780 \\
\hline 9.12 & 148.3358 & 126.6121 \\
\hline 10.03 & 142.4273 & 119.4627 \\
\hline 10.94 & 140.5581 & 115.6458 \\
\hline & & \\
\hline
\end{tabular}

$s[\mathrm{MPa}]$

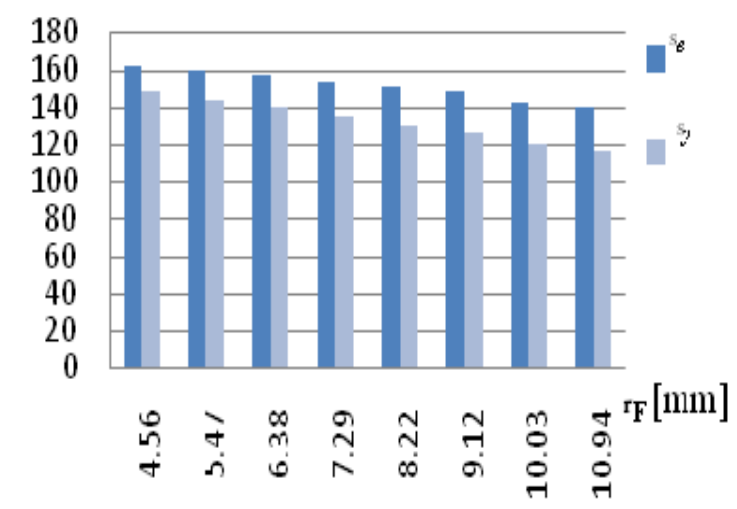

Figure 4. Equivalent stress $\sigma_{e}$ and normal stress $\sigma_{y}$ in function of fillet radius $\rho_{F}$

Fig. 4 shows the functional relationship between various values of fillet radius $\rho_{F}$ and equivalent stresses $\sigma_{e}$ and normal stresses $\sigma_{y}$ for the analyzed gear. These graphs show again a fact that tooth root stresses become less as fillet radius $\rho_{F}$ grows up.

Hence, stresses were still with high values and another analysis has been taken. In order to get critical section stresses with lower values, gear tooth root with two fillet radii are analyzed [1]. It is supposed that two fillet radii ("two level approach" in root) act as "disencumber notch" for stresses and the tooth root stress concentration will be lower. Nevertheless, analyses show that is not always correct and it is possible to get higher tooth root stresses with two fillet radius than only with one for the same determined gear (Table 3).

It is possible to present graphs of all before described samples in this paper, presenting Von Mises and normal stresses (Fig.5.) in function of tooth root fillet radius $\rho_{F 1}$ and $\rho_{F 2}$.

Considering case $f$ it can be seen that Von Mises and normal stresses are less significant on the lower fillet radius, but they are higher on the upper fillet radius. For driven gear, on the upper tooth root fillet radius, equivalent stresses are $1 \%$ and normal stresses $6 \%$ 
higher, while on the lower fillet radius equivalent stresses are $18 \%$ and normal stresses $52 \%$ less.

Cases $b$ (less stresses for the both of gears) and $f$ (approximate same stress values with compared for the both of gears) have the best results.

Considering all variants of $f$ samples it can be concluded that stresses, Von Mises and normal, become less as upper fillet radius $\rho_{F 1}$ becomes less, so, $f 2$ sample is the most available. If rest of dimensions stay unchanged, it is possible to make mesh follow of driving and driven gear of same tooth root dimensions.

Case $b 3$ comparing sample $b$ has different lower radius $\rho_{F 2}$ (Table 3 ). Gear has less stresses on lower fillet radius: equivalent stress is $14 \%$ less, and on upper fillet: equivalent stress is for $2 \%$ and normal stress for $22 \%$ less. It means that $b 3$ tooth root form, according to stress condition, is quite available for the driven gear, because this gear has less stresses on both of fillet radius, upper and lower.

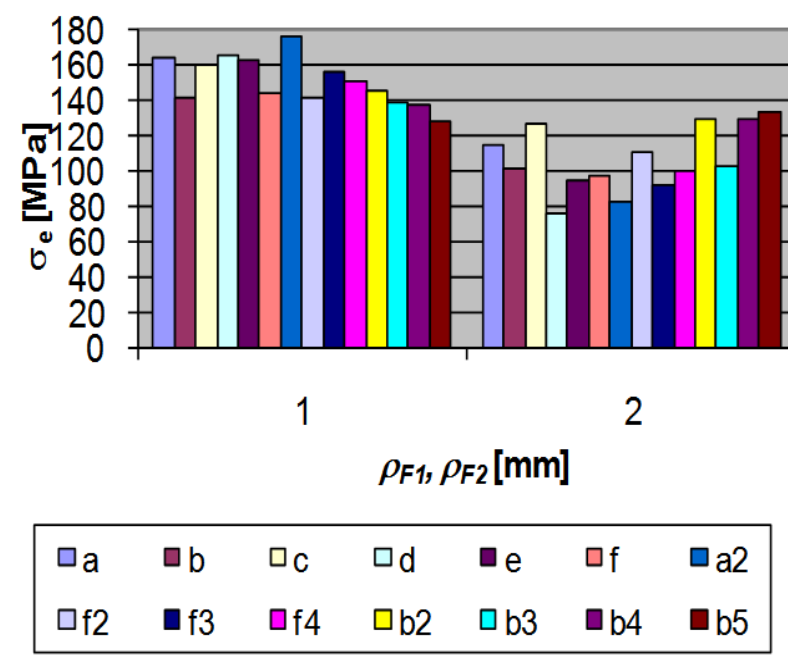

(a)

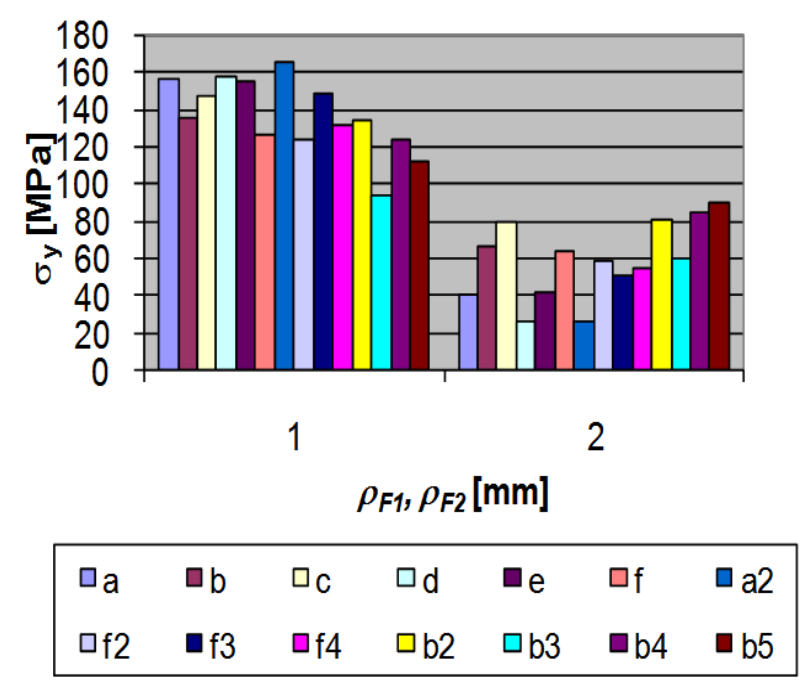

(b)

Figure 5. Equivalent (a) and normal (b) stress values in gear tooth root critical section with two different fillet radius $\rho F 1$ and $\rho F 2$ values

Figure 6 and figure 7 show 3D finite element model for Von Mises (equivalent) stresses for a driven gear tooth (critical section) in case of normal force $F_{b n}$ acting in a contact point B. Figure 6 shows gear tooth root with one fillet radius $\left(\rho_{F}=7,29 \mathrm{~mm}\right)$ and figure 7 shows gear tooth root with two fillet radii, case b2 (Table 3).

These analysis show that stresses get less as $h_{s}$ dimension grows up, but it has to take care of its value to allow gears mesh follow. It is not necessary that tooth root dimensions have to be the same for driving and driven gear to allow gear mesh follow. Investigations of gears with two tooth root fillet radius show that increase of upper fillet radius $\rho_{F l}$ get reduction of stresses. So, in order to get stress reduction and appropriate tooth root state condition it is necessary to modify these two parameters.

It is important to say that it is not possible to realize in practice gear mesh of every combination of tooth foot radius presented in Table 3. It refers especially to cases where parameter $h_{s}$ has higher values (all $\boldsymbol{b}$ tooth root samples), although it is more appropriate case in aspect of stresses (for these instances stresses are reduced) it is not possible to realize two same dimensions gear mesh follow because gears would intermesh each other. However, even these samples are important for finite conclusions in this investigation. In some cases less $h_{s}$ values give less stresses and it can be concluded that with good tooth root dimensions selection, although it is not necessary for pinion and gear to have same form and dimensions, stress reduction can be significant.

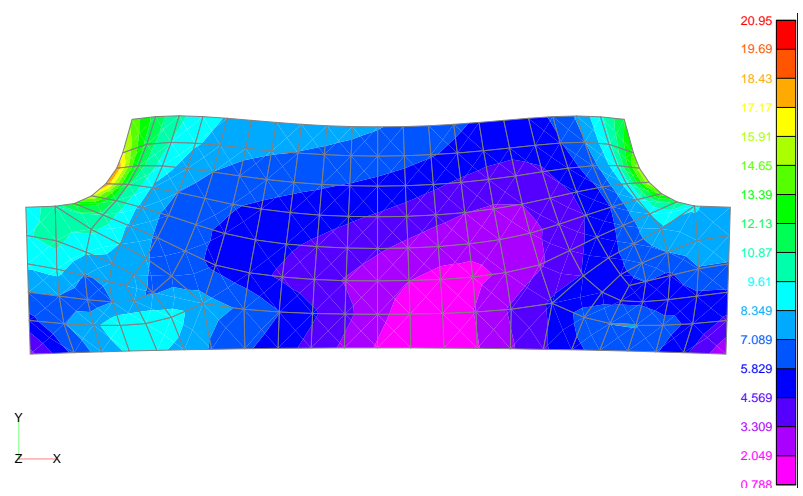

Figure 6. 3D finite element model for Von Mises stresses, one fillet radius $\left(\rho_{F}=7,29 \mathrm{~mm}\right)$

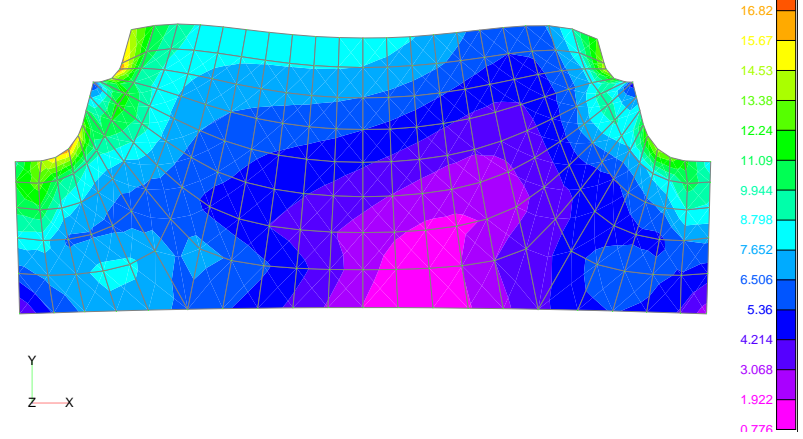

Figure 7. 3D finite element model for Von Mises stresses, two fillet radii, case b2

\section{CONCLUSION}

Topic of this paper is forming efficient and convenient numerical model for the determination of tooth root 
phenomena caused by geometrical discontinuity under static and cyclic loads. Results in this research show good agreement with analytical results, so this methodology may apply in practice.

The most important are tooth root stresses caused by load in the inner contact point of mesh, because they are the greatest and the most important for failure appearance in a tooth root.

It can be concluded, analyzing results of this research, that at gear with one tooth root fillet radius, stresses reduce as tooth fillet radius grows up.

It is supposed that two fillet radius ("two level approach" in root) act as "disencumber notch" for stresses and the tooth root stress concentration will be lower. Nevertheless, analyses show that is not always correct and it is possible to get higher tooth root stresses with two fillet radius than only with one for the same determined gear.

Reduction of stress concentration acts directly on gear service life elongation and increases safety factor $S_{F}$ on that place [4]. This paper shows that appropriate fillet radius selection can increase tooth root stresses in its critical section even by $30 \%$. It was an intention of this research, because in that case it could succeed better tooth root load capacity and service life elongation.

Although tooth flanks stresses are more important for damages and failure appearance, tooth root stresses should not be neglected. Damage and breakage of teeth and failures of large and highly stressed gear transmitters are a potential danger regarding personal safety and can cause an important material loss. Because of that it is good to continue further research in this field.

\section{REFERENCES}

[1] Linke, H.: Stirnrad-verzahnung, Berechnung, Werkstoffe, Fertigung, Carl Hanser Verlag München, Wien, 2002.

[2] Nastran, Application manual, The Macneelschwendler Corporation, 1990.

[3] Ristić, D.: Numerical Stress Concentration Analysis of a Driven Gear Tooth Root With Two Fillet Radius, Scientific Technical Review, YU ISSN 1820-0206, Vol. LVIX, No. 3-4, pp. 69-77, 2009.

[4] Kramberger, J., Šraml, M., Potrč, I. and Flašker, J.: Numerical calculation of bending fatigue life of thin-rim spur gears, Engineering Fracture Mechanics 71, pp. 647-656, 2004.

[5] Kojić, M., Slavković R., Živković M. and Grujović N.: Metod konačnih elemenata, Linearna analiza, Kragujevac, 1998.

[6] Bathe, K.J. and Wilson, E.L.: Numerical Methods in Finite Element Analysis, Prentice-Hill, inc Englewood Cliffs, New Jersey, 1976.

[7] Ristić D. and Milosavljević, D.: Numerical Model For The Critical Stress Determination In Spur
Gears - Case Of A Driven Gear, 11th International Conference on Accomplishments in Electrical and Mechanical Engineering and Information Technology, DEMI 2013, pp. 163-168, Faculty of Mechanical Engineering, Banja Luka, 2013.

[8] Ristić D. and Kramberger J., Numerical Determination Of Critical Stresses And Crack Growth In A Spur Gear Tooth Root, Third Serbian (28th $\mathrm{Yu}$ ) Congress on Theoretical and Applied Mechanics, C-49, pp. 744-756, Vlasina lake, Serbia, 2011.

[9] Nikolić V.: Mechanical Analysis of Gear Transmiters Elements, Monograph, Kragujevac 1999.

[10] Kapelevich A. and Shekhtman Y., Gear Tooth Fillet Profile Optimization, Gear Solutions, pp. 6269, 2009.

[11] Hebbal1 M.S. and. Sheeparamatti, B.G.:A Study on Reducing the Root Fillet Stress in Spur Gear Using Internal Stress Relieving Feature of Different Shapes, International Journal of Recent Trends in Engineering, Vol. 1, No. 5, pp. 163 - 165, 2009.

\section{ЗАВИСНОСТ ИЗМЕБУ НАПОНА У КОРЕНУ ЗУПЦА ЗУПЧАНИКА И РАДИЈУСА ПОДНОЖНОГ ЗАОБЉЕЊА}

\section{Даниела Ристић, Јанез Крамбергер}

Носивост зупца у великој мери зависи од главних параметара који одређују облик профила зупца. Проблем облика профила зупчаника одувек је привлачио пажњу стручњака. Кад је реч о носивости подножја зупца зупчаника, о чему ће се највише говорити у овом раду, врло велики утицај има облик подножја зупца, односно радијус прелазног заобљења у корену зупцу. Посебна пажња усмерена је на радијус подножног заобљења корена зупца у критичном пресеку. Познато је да прва прслина у подножју зупца зупчаника настаје због концентрације напона на том месту. Управо зато, предмет даљег истраживања овог рада је усмерен на изналажење оптималног облика прелазног заобљења у подножју зупца зупчаника са циљем да се добије минимална вредност концентрације напона. У циљу брзог и ефикасног рада у испитивању је примењена метода коначних елемената (МКЕ) при симулацији стварних радних услова. Резултати испитивања су приказани кроз еквивалентне (Von Mises) и нормалне напоне у односу на различите вредности радијуса подножног заобљења зубаца испитиваног зупчаника у два случаја: први је анализа са само једним подножним заобљењем $\left(\rho_{\mathrm{F}}\right)$ и други са два $\left(\rho_{\mathrm{F} 1}\right.$ и $\left.\rho_{\mathrm{F} 2}\right)$. 
Table 3. Equivalent and normal stress values for the tensile side of driven gear for a different tooth root shapes with two fillet radius $\rho_{F 1}$ and $\rho_{F 2}$

\begin{tabular}{|c|c|c|c|c|c|c|c|c|c|}
\hline $\begin{array}{l}\text { Tooth } \\
\text { root } \\
\text { fillet } \\
\text { radius } \\
\text { form }\end{array}$ & \multicolumn{2}{|c|}{$\begin{array}{c}\text { Von Mises stresses } \\
{[\mathrm{MPa}]}\end{array}$} & \multicolumn{2}{|c|}{$\begin{array}{c}\text { Normal stresses } \\
{[\mathrm{MPa}]}\end{array}$} & $\begin{array}{l}\text { Tooth } \\
\text { root } \\
\text { fillet } \\
\text { radius } \\
\text { form }\end{array}$ & \multicolumn{2}{|c|}{$\begin{array}{c}\text { Von Mises stresses } \\
{[\mathrm{MPa}]}\end{array}$} & \multicolumn{2}{|c|}{$\begin{array}{c}\text { Normal stresses } \\
{[\mathrm{MPa}]}\end{array}$} \\
\hline \multirow{4}{*}{$a$} & \multicolumn{4}{|c|}{ Gear tooth root fillet radius dimensions } & \multirow{4}{*}{$f 2$} & \multicolumn{4}{|c|}{ Gear tooth root fillet radius dimensions } \\
\hline & $t_{o}$ & $h_{s}$ & $\rho_{F I}$ & $\rho_{F 2}$ & & $t_{o}$ & $h_{s}$ & $\rho_{F 1}$ & $\rho_{F 2}$ \\
\hline & $0,1 m$ & $0,05 m$ & $0,1 m$ & $0,2 m$ & & $0,1 m$ & $0,125 m$ & $0,3 m$ & $0,2 m$ \\
\hline & $2,4 \mathrm{~mm}$ & $1,2 \mathrm{~mm}$ & $2,4 \mathrm{~mm}$ & $4,8 \mathrm{~mm}$ & & $2,4 \mathrm{~mm}$ & $3 \mathrm{~mm}$ & $7,2 \mathrm{~mm}$ & $4,8 \mathrm{~mm}$ \\
\hline$\rho_{F 1}$ & \multicolumn{2}{|c|}{194,0668} & \multicolumn{2}{|c|}{184,7749} & $\rho_{F 1}$ & \multicolumn{2}{|c|}{165,6977} & \multicolumn{2}{|c|}{144,7214} \\
\hline$\rho_{F 2}$ & \multicolumn{2}{|c|}{119,9051} & \multicolumn{2}{|c|}{48,8787} & $\rho_{F 2}$ & \multicolumn{2}{|c|}{128,8913} & \multicolumn{2}{|c|}{70,1433} \\
\hline \multirow{4}{*}{$b$} & \multicolumn{4}{|c|}{ Gear tooth root fillet radius dimensions } & \multirow{4}{*}{$f 3$} & \multicolumn{4}{|c|}{ Gear tooth root fillet radius dimensions } \\
\hline & $t_{o}$ & $h_{s}$ & $\rho_{F 1}$ & $\rho_{F 2}$ & & $t_{o}$ & $h_{s}$ & $\rho_{F 1}$ & $\rho_{F 2}$ \\
\hline & $0,1 m$ & $0,25 m$ & $0,1 m$ & $0,2 m$ & & $0,1 m$ & $0,125 m$ & $0,1 m$ & $0,2 m$ \\
\hline & $2,4 \mathrm{~mm}$ & $6 \mathrm{~mm}$ & $2,4 \mathrm{~mm}$ & $4,8 \mathrm{~mm}$ & & $2,4 \mathrm{~mm}$ & $3 \mathrm{~mm}$ & $2,4 \mathrm{~mm}$ & $4,8 \mathrm{~mm}$ \\
\hline$\rho_{F 1}$ & \multicolumn{2}{|c|}{167,4429} & \multicolumn{2}{|c|}{157,7621} & $\rho_{F 1}$ & 18 & 599 & & 164 \\
\hline$\rho_{F 2}$ & 11 & 338 & & & $\rho_{F 2}$ & 10 & 108 & & 01 \\
\hline & Gea & oth root fi & radius din & sions & & Gea & oth root fi & radius dir & sions \\
\hline $\mathcal{c}$ & $t_{o}$ & $h_{s}$ & $\rho_{F 1}$ & $\rho_{F 2}$ & $f 4$ & $t_{o}$ & $h_{s}$ & $\rho_{F 1}$ & $\rho_{F 2}$ \\
\hline$c$ & $0,05 m$ & $0,1 m$ & $0,1 m$ & $0,2 m$ & $J^{4}$ & $0,1 m$ & $0,125 m$ & $0,2 m$ & $0,2 m$ \\
\hline & $1,2 \mathrm{~mm}$ & $2,4 \mathrm{~mm}$ & $2,4 \mathrm{~mm}$ & $4,8 \mathrm{~mm}$ & & $2,4 \mathrm{~mm}$ & $3 \mathrm{~mm}$ & $4,8 \mathrm{~mm}$ & $4,8 \mathrm{~mm}$ \\
\hline$\rho_{F 1}$ & 13 & 541 & & 252 & $\rho_{F I}$ & 17 & 510 & & 481 \\
\hline$\rho_{F 2}$ & 12 & 788 & & & $\rho_{F 2}$ & 11 & 340 & & 79 \\
\hline & Gea & oth root fi & radius din & sions & & Gea & oth root fi & radius dir & sions \\
\hline$d$ & $t_{o}$ & $h_{s}$ & $\rho_{F I}$ & $\rho_{F 2}$ & b2 & $t_{o}$ & $h_{s}$ & $\rho_{F 1}$ & $\rho_{F 2}$ \\
\hline$a$ & $0,2 m$ & $0,1 m$ & $0,1 m$ & $0,2 m$ & $D 2$ & $0,1 m$ & $0,3 m$ & $0,1 m$ & $0,2 m$ \\
\hline & $4,8 \mathrm{~mm}$ & $2,4 \mathrm{~mm}$ & $2,4 \mathrm{~mm}$ & $4,8 \mathrm{~mm}$ & & $2,4 \mathrm{~mm}$ & $7,2 \mathrm{~mm}$ & $2,4 \mathrm{~mm}$ & $4,8 \mathrm{~mm}$ \\
\hline$\rho_{F 1}$ & 19 & 911 & & 748 & $\rho_{F 1}$ & 16 & 541 & & 374 \\
\hline$\rho_{F 2}$ & & & & 100 & $\rho_{F 2}$ & 15 & 703 & & 47 \\
\hline & Gea & oth root fi & radius din & sions & & Gea & oth root fi & radius dir & sions \\
\hline & $t_{o}$ & $h_{s}$ & $\rho_{F I}$ & $\rho_{F 2}$ & b3 & $t_{o}$ & $h_{s}$ & $\rho_{F 1}$ & $\rho_{F 2}$ \\
\hline $\boldsymbol{e}$ & $0,1 m$ & $0,1 m$ & $0,1 m$ & $0,2 m$ & b3 & $0,1 m$ & $0,25 m$ & $0,1 m$ & $0,3 m$ \\
\hline & $2,4 \mathrm{~mm}$ & $2,4 \mathrm{~mm}$ & $2,4 \mathrm{~mm}$ & $4,8 \mathrm{~mm}$ & & $2,4 \mathrm{~mm}$ & $6 \mathrm{~mm}$ & $2,4 \mathrm{~mm}$ & $7,2 \mathrm{~mm}$ \\
\hline$\rho_{F 1}$ & 19 & 468 & & 204 & $\rho_{F 1}$ & 16 & 687 & & 312 \\
\hline$\rho_{F 2}$ & 11 & 184 & & & $\rho_{F 2}$ & 12 & 024 & & 22 \\
\hline & Gea & oth root fi & radius din & sions & & Gea & oth root fi & radius dir & sions \\
\hline & $t_{o}$ & $h_{s}$ & $\rho_{F 1}$ & $\rho_{F 2}$ & h4 & $t_{o}$ & $h_{s}$ & $\rho_{F 1}$ & $\rho_{F 2}$ \\
\hline $\boldsymbol{J}$ & $0,1 m$ & $0,1 m$ & $0,3 m$ & $0,2 m$ & b4 & $0,1 m$ & $0,25 m$ & $0,2 m$ & $0,2 m$ \\
\hline & $2,4 \mathrm{~mm}$ & $2,4 \mathrm{~mm}$ & $7,2 \mathrm{~mm}$ & $4,8 \mathrm{~mm}$ & & $2,4 \mathrm{~mm}$ & $6 \mathrm{~mm}$ & $4,8 \mathrm{~mm}$ & $4,8 \mathrm{~mm}$ \\
\hline$\rho_{F 1}$ & 16 & 420 & & 602 & $\rho_{F 1}$ & 16 & 604 & & 562 \\
\hline$\rho_{F 2}$ & 13 & 327 & & & $\rho_{F 2}$ & & 319 & & 61 \\
\hline & Gea & oth root fi & radius din & sions & & Gea & oth root fi & radius dir & sions \\
\hline ? & $t_{o}$ & $h_{s}$ & $\rho_{F I}$ & $\rho_{F 2}$ & h5 & $t_{o}$ & $h_{s}$ & $\rho_{F 1}$ & $\rho_{F 2}$ \\
\hline ar & $0,125 m$ & $0,05 m$ & $0,1 m$ & $0,2 m$ & נס & $0,1 m$ & $0,25 m$ & $0,3 m$ & $0,2 m$ \\
\hline & $3 \mathrm{~mm}$ & $1,2 \mathrm{~mm}$ & $2,4 \mathrm{~mm}$ & $4,8 \mathrm{~mm}$ & & $2,4 \mathrm{~mm}$ & $6 \mathrm{~mm}$ & $7,2 \mathrm{~mm}$ & $4,8 \mathrm{~mm}$ \\
\hline$\rho_{F 1}$ & 21 & 066 & & 825 & $\rho_{F 1}$ & 15 & 770 & & 013 \\
\hline$\rho_{F 2}$ & & & & 05 & $\rho_{F 2}$ & 15 & 784 & & 536 \\
\hline
\end{tabular}

